\title{
TAHAP KEBIASAAN, KEFAHAMAN KONSEPTUAL, PENGUASAAN DAN MINAT TERHADAP KEMAHIRAN PROSES SAINS DALAM KALANGAN GURU SAINS
}

\author{
${ }^{1}$ Ang Shu Zen, ${ }^{2}$ Ong Eng Tek \\ ${ }^{1}$ SJKC Choong Hua 2, 3550 Bidor, Perak \\ ${ }^{2}$ Universiti Pendidikan Sultan Idris, 35900 Tanjung Malim, Perak \\ *emel : ong.engtek@fpm.upsi.edu.my
}

Received : 16 Oktober 2018; Accepted : 20 November 2018; Published : 27 Disember 2018

\begin{abstract}
Abstrak
Kajian ini bertujuan untuk mengenal pasti perbezaan dalam tahap kebiasaan, kefahaman konseptual, penguasaan dan minat terhadap Kemahiran Proses Sains (KPS) dalam kalangan guru sains Sekolah Jenis Kebangsaan Cina (SJKC) berdasarkan pengalaman mengajar, opsyen, tahap yang diajar, umur dan bilangan kursus sains yang pernah dihadiri. Kajian ini menggunakan model penilaian jenis Context Input Process Product (CIPP) yang diasaskan oleh Stufflebeam. Pendekatan kuantitatif dengan kajian tinjauan keratan rentas digunakan dalam kajian ini. Teknik pensampelan yang digunakan adalah pensampelan rawak kluster yang melibatkan kesemua 70 orang guru sains SJKC di kluster Daerah Muallim di Perak. Tiga jenis instrumen kajian digunakan iaitu soal selidik, ujian bertulis dan ujian objektif aneka pilihan. Analisis inferens yang melibatkan Ujian Mann-Whitney dan Ujian KruskalWallis digunakan untuk mengenal pasti perbezaan berdasarkan kumpulan demografik. Dapatan kajian menunjukkan, dari segi tahap kebiasaan dan tahap kefahaman konseptual, terdapat perbezaan dari segi pengalaman guru. Dari segi tahap penguasaan, terdapat perbezaan dari segi opsyen dan umur guru. Dari segi tahap minat pula, terdapat perbezaan dalam kalangan guru yang telah menghadiri kursus.
\end{abstract}

Kata kunci Tahap Kebiasaan, Kefahaman Konseptual, Penguasaan, Minat, Kemahiran Proses Sains.

\begin{abstract}
This research aims to identify the differences in the levels of familiarity, conceptual understanding, mastery, and interests towards science process skills (SPS) amongst science teachers at Chinese National-type Schools Chinese or SJKC by teaching experience, option, level taught, age, and the number of courses attended. This research utilizes the evaluation model of Context Input Process Product, propounded by Stufflebeam. The quantitative approach employed was that of the cross-sectional survey. Using the random cluster sampling, all the 70 science teachers of SJKC
\end{abstract}


TAHAP KEBIASAAN, KEFAHAMAN KONSEPTUAL, PENGUASAAN DAN MINAT TERHADAP KEMAHIRAN PROSES SAINS DALAM KALANGAN GURU SAINS SJKC

in the cluster of Muallim District in Perak were involved in this study. Three research instruments were used, namely the questionnaire, written test, and multiple-choice test. The inferential statistics by means of the Mann-Whitney test and the Kruskal-Wallis test were used to identify the differences by the demographic groups. The findings indicate that, in terms of familiarity level and conceptual understanding level, there were differences among teachers teaching experience. In terms of mastery level, there were differences in among teachers option. In terms of the level of interest there were differences among teachers who had attended the courses.

Keywords Familiarity Level, Conceptual Understanding, Mastery, Interests, Science Process Skills.

\section{PENGENALAN}

Secara keseluruhan, murid-murid Malaysia yang berumur 15 tahun dalam pentaksiran antarabangsa PISA (The Programme for International Student Assessment) pada tahun 2015 mencapai satu skor purata sebanyak 443 dalam sains berbanding dengan skor purata antarabangsa pada tahap 466 (Organisation for Economic Cooperation and Development [OECD], 2017). Jelas sekali, pencapaian Malaysia dalam PISA 2105 adalah di bawah pencapaian purata antarabangsa. Tambahan pula, antara 72 buah negara yang mengambil bahagian, Malaysia menduduki tangga ke 46 dalam pencapaian sains dalam PISA 2015 (OECD, 2017, p. 244). Begitu juga dalam pencapaian matematik di mana Malaysia mencapai satu skor purata sebanyak 446 dalam matematik berbanding dengan skor purata antarabangsa pada tahap 462. Ini seterusnya meletakkan Malaysia pada tangga ke 44 apabila dibandingkan dengan 72 buah negara yang mengambil bahagian.

Sebagaimana yang tersurat dalam Pelan Pembangunan Pendidikan Malaysia (PPPM) (KPM, 2012), Kerajaan Malaysia telah menetapkan satu aspirasi untuk meletakkan Malaysia dalam kelompok sepertiga teratas dalam pentaksiran antarabangsa TIMSS (Trends in International Mathematics and Science Study) dan PISA dalam tempoh 15 tahun yang akan datang. Ini bermakna adalah penting bagi setiap orang murid untuk menguasai mata pelajaran sains dan matematik dalam usaha untuk mencapai aspirasi tersebut.

\section{PERNYATAAN MASALAH}

Kemahiran saintifik yang meliputi KPS dan kemahiran manipulatif merupakan elemen yang sangat penting dalam pembelajaran sains. Menurut Shahrir dan Suziela (2011), pembelajaran sains menjadi lebih bermakna sekiranya murid memahami konsep sains yang wujud di sebalik pembelajaran tersebut. Modul Kemahiran Proses Sains yang diterbitkan oleh Bahagian Pembangunan Kurikulum (2013) menegaskan bahawa pengoperasian KPS dalam pembelajaran dan pemudahcaraan (PdPc) merupakan satu pendekatan pedagogi dalam menimbulkan minat dan keseronokan murid untuk terlibat secara aktif dalam proses PdPc. Lantaran itu, pengetahuan guru- 
guru sains perlu merangkumi pengetahuan dan kemahiran dalam melaksanakan PdPC yang berteraskan KPS dalam usaha untuk menarik minat dan menimbulkan keseronokan dalam kalangan murid semasa mereka mempelajari sains. Hal ini adalah penting kerana kajian-kajian lepas menunjukkan kebanyakan murid mempunyai sikap yang negatif terhadap sains dan sebahagian murid pula tidak berminat terhadap sains (Aziz Nordin \& Lin, 2011; Chin, 2012). Dapatan daripada kajian Chin (2012) menunjukkan bahawa kefahaman dan minat murid-murid terhadap mata pelajaran sains telah meningkat setelah beliau melaksanakan kaedah pembelajaran koperatif dan menerapkan unsur kemahiran saintifik dalam PdPc.

Berdasarkan dokumen polisi Kementerian Pendidikan Malaysia (2013), matlamat Kurikulum Standard Sekolah Rendah (KSSR) adalah untuk melengkapkan murid kita dengan ilmu pengetahuan sains, kemahiran saintifik, sikap saintifik dan nilai murni. Memandangkan konsep KPS telah pun diterapkan dalam sukatan pelajaran sains mulai Tahap 1 (Tahun 1-3), maka guru sains diwajibkan untuk mengajar kemahiran ini kepada murid. Selain itu, KPS digunakan semasa merancang dan menjalankan penyiasatan sains (Azraai, Fazilah \& Othman, 2016). Ini bermakna guru sains perlu banyak merancang aktiviti amali agar kemahiran saintifik dapat diterapkan apabila murid merancang, mengendali, dan menganalisis data menggunakan pelbagai peralatan (Berg, 2008).

Cabaran utama yang dihadapi oleh KPM kini ialah keupayaan guru sains untuk menyampai dan menerapkan KPS dalam PdPc secara berkesan. Tan dan Chin (2001) menghujah bahawa kegagalan guru sains dalam memahami konsep KPS akan mengakibatkan kegagalan penerapannya dalam aktiviti PdPc sains. Kajian yang dijalankan oleh Hariah dan Chin (2012) terhadap guru-guru pelatih major sains di Institut Pendidikan Guru mendapati guru pelatih menulis KPS dalam rancangan pengajaran harian semata-mata untuk memenuhi keperluan format sahaja dan mereka tidak pernah membuat refleksi tentang masalah penerapan KPS dalam PdPc. Di samping itu, Hariah dan Chin (2012) juga mendapati KPS kurang diberikan penekanan oleh guru pelatih dalam PdPc sains dan masalah kekurangan dalam penekanan KPS ini disumbangkan oleh fenomena di mana guru pelatih sendiri pun kurang memahami KPS. Sorotan kajian lepas menunjukkan bahawa, walaupun banyak kajian telah dilaksanakan untuk meninjau tahap penguasaan KPS dalam kalangan murid (Ong \& Johairi, 2011; Ong \& Ruthven, 2005; Mohd Azri \& Siti Shahida, 2016; Wun \& Sunita, 2015), namun kajian untuk meninjau tahap penguasaan dalam kalangan guru amat terhad dan kebanyakan kajian ini dibuat di luar negara.

Penelitian dapatan kajian-kajian lepas menunjukkan bahawa tahap pelaksanaan kemahiran proses sains yang rendah oleh guru sains dan juga pengakuan daripada ramai guru sains yang menyatakan bahawa mereka kurang bersedia untuk menerapkan KPS dalam PdPc (Abu Hassan Kassim, 2007). Penguasaan KPS yang rendah dalam kalangan guru sains akan menyebabkan penguasaan KPS, kemahiran manipulatif dan pengetahuan saintifik dalam kalangan murid sekolah berada dalam tahap yang rendah juga (Abungu, Okere, \& Wachanga, 2014). Ini seterusnya menjadi satu justifikasi tambahan kepada kepentingan untuk meninjau tahap penguasaan konsep KPS dalam kalangan guru sains. 
TAHAP KEBIASAAN, KEFAHAMAN KONSEPTUAL, PENGUASAAN DAN MINAT TERHADAP KEMAHIRAN PROSES SAINS DALAM KALANGAN GURU SAINS SJKC

\section{PERSOALAN KAJIAN}

Berdasarkan permasalahan kajian yang dihuraikan dan juga limitasi yang ada di mana kajian akan dihadkan kepada guru-guru sains di SJKC, maka berikut merupakan persoalan kajian:

Adakah terdapat perbezaan dari segi tahap kebiasaan, tahap kefahaman konseptual, tahap penguasaan dan tahap minat terhadap KPS berdasarkan pengalaman mengajar, opsyen, tahap yang diajar, umur dan bilangan kursus sains yang dihadiri dalam kalangan guru sains Sekolah Jenis Kebangsaan Cina?

\section{KERANGKA KONSEP KAJIAN}

Kerangka teori yang dikaitkan dan diaplikasikan dalam kajian ini ialah Model Penilaian CIPP (Context-Input-Process-Product) yang dipelopori oleh Daniel Stufflebeam pada tahun 1971. Model CIPP dinamakan atas perkataan pertama bagi setiap penilaian yang digunakan untuk membentuk singkatan (acronym), iaitu Konteks (Context), Input, Proses (Process) dan Produk (Product). Menurut Stufflebeam (1971), penilaian didefinisikan sebagai proses mengenal pasti, memperoleh dan menyediakan maklumat yang berguna bagi membuat keputusan semasa mempertimbangkan pilihan-pilihan yang ada. Model CIPP adalah satu model yang digunakan untuk tujuan menilai dan tujuan utama penilaian ini adalah untuk mengaitkan matlamat, konteks, input dan proses dengan hasil program yang dinilai. Selain itu, Model CIPP merupakan model penilaian yang berorientasikan objektif. Model ini berbeza dengan model-model penilaian yang lain kerana model ini memberi fokus kepada proses membuat keputusan. Ini bermaksud model ini bertujuan untuk membantu pengurus atau pentadbir membuat keputusan tentang sesuatu program (Worthern \& Sanders, 1998). Model ini digunakan untuk memperbaiki sesuatu program dengan menggunakan maklumat yang ada dan lebih menekankan pengawalan mutu.

Penilaian konteks adalah kajian tentang persekitaran sesuatu program. Tujuan penilaian konteks adalah untuk menentukan kesesuaian persekitaran dalam membantu pencapaian matlamat dan objektif program. Penilaian input pula menumpu kepada perancangan, strategi, prosedur dan sumber yang diperlukan ke arah pencapaian matlamat dan objektif program. Sebagai contohnya, sikap guru dan keyakinan guru perlu dinilai kerana guru merupakan sumber yang penting untuk memastikan kejayaan program yang dinilai. Dalam pada itu, penilaian proses adalah berfokuskan proses pelaksanaan sesuatu program yang bertujuan untuk membuat penambahbaikan bagi kekurangan program. Contohnya, penilaian proses boleh dijalankan ke atas cara penyampaian PdPc guru, cara guru menilai projek dan kursus yang diikuti oleh guru. Penilaian yang terakhir ialah penilaian produk yang mengukur dan menganalisis hasil serta kesan sesuatu program. Contoh penilaian produk ialah hasil perubahan sikap murid dan pencapaian murid dalam mata pelajaran yang dinilai.

Dalam kajian ini, hanya satu penilaian sahaja yang diterap, yakni penilaian proses. Hal ini adalah kerana penilaian proses merupakan satu penilaian yang 
digunakan untuk menilai proses pelaksanaan sesuatu program atau kursus. Tambahan pula, penerapan KPS oleh guru sains dalam PdPc adalah satu proses yang berterusan dan ia dilaksanakan setiap hari merentas sekolah di Malaysia. Oleh itu, dalam kajian ini, tahap kebiasaan, tahap kefahaman konseptual, tahap penguasaan dan tahap minat terhadap KPS dalam kalangan guru sains SJKC dikenal pasti kerana ia merupakan faktor-faktor yang mempengaruhi penerapan KPS oleh guru-guru sains SJKC dalam PdPc. Model CIPP yang telah dibincangkan dirumuskan dalam Rajah 1.

Konteks

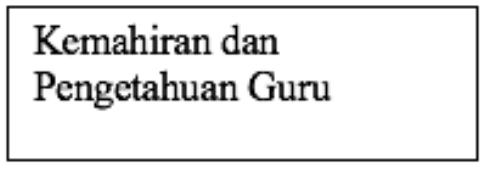

Produk

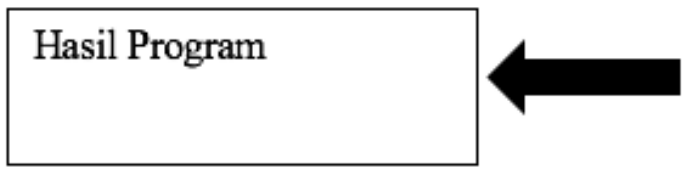

\section{Input}

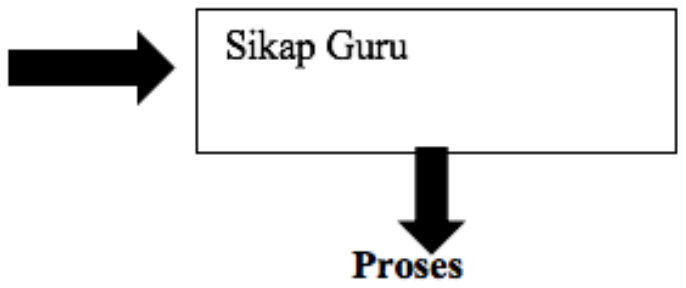

Proses Pelaksanaan

Program

Rajah 1 Rumusan Model CIPP

\section{METODOLOGI}

\section{Reka Bentuk Kajian}

Kajian ini merupakan kajian kuantitatif berbentuk deskriptif yang bertujuan untuk menerangkan fenomena yang sedang berlaku. Kajian ini menggunakan reka bentuk tinjauan jenis keratan rentas (cross-sectional survey) kerana pengumpulan data hanya sekali sahaja daripada responden yang sama (Ary, Jacobs, Razavieh, \& Sorenson, 2006).

\section{Instrumentasi}

Instrumen pertama ialah soal selidik yang digunakan untuk mengenal pasti tahap kebiasaan dan minat guru sains SJKC terhadap KPS. Soal selidik ini pernah digunakan oleh Miles (2010). Soal selidik ini terdiri daripada dua bahagian. Bahagian pertama adalah berkaitan dengan maklumat demografik responden, termasuklah jantina, umur, pengalaman mengajar, tahap yang diajar, mata pelajaran yang diajar, pengalaman mengajar mata pelajaran lain, bilangan kursus sains yang pernah dihadiri, tahap pendidikan ikhtisas dan bidang pengkhususan (atau opsyen) dalam pendidikan. Bahagian kedua pula dibahagikan kepada bahagian A dan bahagian B. Bahagian A digunakan untuk mengenal pasti tahap kebiasaan guru sains SJKC terhadap KPS, manakala bahagian B berfungsi untuk mengukur minat guru sains 
TAHAP KEBIASAAN, KEFAHAMAN KONSEPTUAL, PENGUASAAN DAN MINAT TERHADAP KEMAHIRAN PROSES SAINS DALAM KALANGAN GURU SAINS SJKC

SJKC terhadap KPS. Dalam bahagian A, responden diminta untuk memilih sama ada "saya tidak biasa dengan kemahiran ini", "saya biasa dengan kemahiran ini, tetapi saya tidak faham" ataupun "saya biasa dengan kemahiran ini dan saya faham maksud kemahiran ini" bagi setiap KPS yang disenaraikan. Jadi, bahagian A adalah bertujuan untuk mengenal pasti tahap kebiasaan guru sains terhadap setiap KPS. Bahagian B adalah untuk mengenal pasti minat guru sains terhadap KPS. Dalam bahagian B pula, responden dikehendaki memilih antara "saya tidak berminat untuk belajar dengan lebih lanjut", "saya berminat untuk belajar dengan lebih lanjut" dan "saya sangat berminat untuk belajar dengan lebih lanjut" bagi setiap KPS.

Instrumen yang kedua ialah ujian bertulis yang digunakan untuk menguji kefahaman konseptual KPS guru sains SJKC. Ujian ini memerlukan responden untuk menulis definisi bagi setiap KPS. Ujian ini pernah digunakan oleh Miles (2010) untuk menguji kefahaman konseptual guru dalam perkhidmatan terhadap KPS. Semasa menjawab ujian ini, para responden dikehendaki menulis definisi bagi setiap KPS dengan menggunakan perkataan sendiri. Selepas itu, data akan dianalisis dengan berpandukan definisi yang telah dikumpulkan oleh pengkaji.

Instrumen yang ketiga dalam kajian ini ialah ujian aneka pilihan yang digunakan untuk melihat tahap penguasaan guru terhadap KPS (Miles, 2010) dalam kalangan guru sains SJKC. Instrumen ini mengandungi 48 soalan yang berkaitan dengan KPS yang mana Miles (2010) telah mengadaptasi daripada 4 sumber berikut, iaitu Ujian Kemahiran Proses Sains Bersepadu II oleh Burns, Okey dan Wise (1985), Ujian Kemahiran Proses Sains Asas oleh Padilla, Cronin dan Twiest (1985), Virginia Standards of Learning Assessments (2007) dan National Assessment of Education Progress (2005) dari Kementerian Pendidikan Amerika Syarikat. Soalan-soalan KPS yang digunakan oleh Miles (2010) digunakan secara total dalam Bahasa Inggeris berdasarkan tiga sebab: (1) guru-guru sains SJKC selesa dengan penggunaan Bahasa Inggeris dan tidak perlu menterjemahkannya ke Bahasa Mandarin, (2) soalan-soalan KPS tersebut pernah ditadbirkan kepada guru-guru sains di luar negara, dan (3) soalan-soalan KPS tersebut telah pun mempunyai kesahan dan kebolehpercayaan yang sesuai. Daripada 48 soalan aneka pilihan ini, terdapat 23 soalan (47.9\%) yang menguji KPS Asas dan 25 soalan (52.1\%) yang menguji KPS Bersepadu.

\section{Pensampelan}

Populasi kajian ini terdiri daripada guru-guru sains sekolah rendah di Perak. Teknik pensampelan rawak kluster digunakan di mana guru-guru sains yang terpilih merupakan guru-guru sains yang mengajar di 23 buah SJKC di kluster Daerah Muallim, Perak yang berada di bawah pengelolaan Kementerian Pendidikan Malaysia. Berdasarkan pensampelan tersebut, maka sejumlah 70 orang guru sains yang terlibat sebagai sampel. Taburan guru-guru sains di SJKC yang terpilih mengikut jantina, umur, pengalaman mengajar sains, bilangan kursus sains yang dihadiri, subjek major dan tahap murid yang diajar dipaparkan dalam Jadual 1. 
Jadual 1 Taburan sampel kajian berdasarkan demografik

\begin{tabular}{lllcc}
\hline & Latar Belakang Sosial & Pemboleh Ubah & Bilangan & Peratus (\%) \\
\hline 1. & Jantina & Lelaki & 12 & 17.1 \\
& & Perempuan & 58 & 82.9 \\
\hline 2. & Umur & $24-30$ tahun & 39 & 55.7 \\
& & $31-35$ tahun & 14 & 20.0 \\
& & $36-40$ tahun & 7 & 10.0 \\
& & $41-45$ tahun & 2 & 2.9 \\
& & 46 tahun dan ke atas $(46+)$ & 8 & 11.4 \\
\hline 3. & Pengalaman Mengajar & $1-5$ tahun & 51 & 72.9 \\
& Sains & $6-10$ tahun & 10 & 14.3 \\
& & 11 tahun dan ke atas $(11+)$ & 9 & 12.8 \\
\hline 4. & Bilangan Kursus Sains & $0-2$ kursus & 42 & 60 \\
& Yang Dihadiri & $3-6$ kursus & 18 & 25.7 \\
& & $7-10$ kursus & 3 & 4.3 \\
& & 11 kursus dan ke atas $(11+)$ & 7 & 10.0 \\
\hline 6. & Tahap Yang Diajar & 1 (Tahun 1-3) & 10 & 14.3 \\
& & Opains & 60 & 85.7 \\
\hline & & Oain-lain & 31 & 44.3 \\
\hline
\end{tabular}

Responden terdiri daripada 12 (17.1\%) orang guru lelaki dan $58(82.9 \%)$ orang guru perempuan. Kebanyakan responden kajian terdiri daripada guru muda yang berada dalam linkungan umur 24 hingga 30 tahun, iaitu seramai 39 orang guru (55.7\%). 20\% responden pula berumur dalam lingkungan 31 sehingga 35 tahun, manakala terdapat $10 \%$ responden yang berumur 36 hingga 40 tahun. Hanya 2 orang guru yang berumur 41 hingga 45 tahun manakala $11.4 \%$ adalah responden yang berumur 46 tahun dan ke atas, iaitu seramai 8 orang. Seramai $51(72.9 \%)$ daripada 70 orang responden adalah guru yang mempunyai pengalaman mengajar sains selama 1 hingga 5 tahun, $10(14.3 \%)$ orang responden telah mengajar sains bagi tempoh 6 hingga 10 tahun, dan $9(12.8 \%)$ orang responden telah mengajar 11 tahun dan ke atas.

Dari segi bilangan kursus sains yang pernah dihadiri, seramai $42(60 \%)$ daripada responden tidak pernah menghadiri atau hanya pernah menghadiri satu atau dua kursus sains, manakala $18(25.7 \%)$ daripada responden pernah menghadiri 3 hingga 6 kursus sains. Seramai 3 orang responden sahaja (4.3\%) yang pernah menghadiri 7 hingga 10 kursus sains, manakala seramai 7 orang responden $(10 \%)$ yang pernah menghadiri 11 kursus dan ke atas. Dari segi opsyen pula, hanya seramai $10(14.3 \%)$ orang responden yang merupakan guru yang beropsyen sains manakala 
TAHAP KEBIASAAN, KEFAHAMAN KONSEPTUAL, PENGUASAAN DAN MINAT TERHADAP KEMAHIRAN PROSES SAINS DALAM KALANGAN GURU SAINS SJKC

$60(85.7 \%)$ orang responden yang lain merupakan guru yang bukan beropsyen sains. Tahap yang diajar oleh guru boleh dibahagikan kepada dua, iaitu Tahap 1 yang terdiri daripada Tahun 1, 2 dan 3 manakala Tahap 2 pula terdiri daripada Tahun 4, 5 dan 6. Hasil analisis daripada soal selidik menunjukkan bahawa bilangan guru yang mengajar Tahap 1 dan Tahap 2 adalah hampir sama, iaitu sebanyak 31 (44.3\%) orang guru yang mengajar sains pada Tahap 1 manakala 39 (55.7\%) orang guru pula yang mengajar sains pada Tahap 2 .

\section{Kaedah Penganalisisan Data}

Ujian Mann-Whitney dan Ujian Kruskal-Wallis dijalankan untuk membandingkan empat tahap (iaitu tahap kebiasaan, tahap kefahaman konseptual, tahap penguasaan dan tahap minat guru sains SJKC terhadap KPS) berdasarkan enam kumpulan demografik, yakni, jantina, umur, pengalaman mengajar sains, bilangan kursus yang pernah dihadiri, opsyen, dan tahap yang diajar. Sekiranya terdapat kesignifikan dalam Ujian Kruskal-Wallis, ini akan diikuti oleh penganalisisan lanjutan melalui Ujian Post-hoc bagi menentukan pasangan-pasangan yang manakah adalah signifikan.

\section{DAPATAN KAJIAN}

Dapatan kajian dilaporkan bagi setiap tahap, iaitu (i) tahap kebiasaan terhadap KPS, (ii) tahap kefahaman konseptual terhadap KPS, (iii) tahap penguasaan terhadap KPS, dan (iv) tahap minat terhadap KPS merentas enam kumpulan demografik, yakni jantina, umur, pengalaman mengajar sains, bilangan kursus yang pernah dihadiri, opsyen, dan tahap yang diajar. Memandangkan terdapatnya enam kumpulan demografik dengan kekangan ruangan dalam manuskrip jurnal, maka hanya perbezaan kumpulan demografik yang signifikan sahaja yang akan dilaporkan.

\section{(i) Analisis Tahap Kebiasaan terhadap KPS}

Hasil analisis Ujian Kruskal-Wallis menunjukkan terdapatnya perbezaan yang signifikan $(\mathrm{p}<.05)$ dalam tahap kebiasaan terhadap KPS berdasarkan pengalaman mengajar sains. Penganalisisan lanjut melalui Ujian Post-Hoc menunjukkan guru yang berpengalaman mengajar 11 tahun dan ke atas mencapai mean rank tahap kebiasaan terhadap KPS yang lebih tinggi dan signifikan $(\mathrm{p}=.011<.05)$ berbanding dengan guru yang berpengalaman mengajar sains antara 1 hingga 5 tahun.

Juga, hasil analisis Ujian Kruskal-Wallis menunjukkan terdapatnya perbezaan yang signifikan $(\mathrm{p}<.05)$ dalam tahap kebiasaan terhadap KPS berdasarkan bilangan kursus sains yang pernah dihadiri oleh responden. Penganalisisan lanjutan melalui Ujian Pos-Hoc mendapati guru yang menghadiri kursus sains sebanyak 3 hingga 6 kali mencapai mean rank tahap kebiasaan terhadap KPS yang lebih tinggi dan signifikan $(\mathrm{p}=.013<.05)$ berbanding dengan guru yang telah menghadiri 0 sehingga 2 kali kursus sains. Tambahan pula, guru yang menghadiri kursus sains 11 kali dan ke atas juga mencapai mean rank tahap kebiasaan terhadap KPS yang lebih tinggi dan signifikan $(\mathrm{p}=.016<.05)$ berbanding dengan guru yang telah menghadiri 0 sehingga 2 kali kursus sains. Hasil analisis ditunjukkan dalam Jadual 2 di bawah. 
Jadual 2 Perbandingan tahap kebiasaan terhadap KPS

\begin{tabular}{cccc|ccc}
\hline Demografik & & $\mathrm{N}$ & Mean Rank & $\mathrm{x}^{2}$ & $\mathrm{~d} f$ & sig. \\
\hline Pengalaman & $1-5$ tahun & 51 & 31.93 & & & \\
Mengajar Sains & $6-10$ tahun & 10 & 41.55 & 8.368 & 2 & 0.015 \\
& $11+$ tahun & 9 & 49.00 & & & \\
\hline Bilangan Kursus & $0-2$ & 42 & 30.15 & & & \\
Sains Yang & $3-6$ & 18 & 42.67 & 10.715 & 3 & 0.013 \\
Pernah Dihadiri & $7-10$ & 3 & 35.83 & & & \\
& $11+$ & 7 & 49.00 & & & \\
\hline
\end{tabular}

(ii) Analisis Tahap Kefahaman Konseptual terhadap KPS

Ujian Kruskal-Wallis menunjukkan bahawa terdapat perbezaan yang signifikan $(\mathrm{p}=.003<.05)$ dalam tahap penguasaan konseptual bagi guru sains berdasarkan pengalaman mengajar sains. Penganalisisan lanjutan melalui Ujian Post-Hoc mendapati bahawa guru yang berpengalaman mengajar 11 tahun dan ke atas mempunyai mean rank tahap kefahaman konseptual terhadap KPS yang lebih tinggi dan signifikan $(\mathrm{p}=.002<.05)$ berbanding dengan guru yang berpengalaman mengajar 1 hingga 5 tahun, dan juga lebih tinggi dan signifikan $(\mathrm{p}=.001<.05)$ berbanding dengan guru yang berpengalaman mengajar selama 6 hingga 10 tahun. Hasil analisis ditunjukkan dalam Jadual 3 di bawah.

Jadual 3 Perbandingan tahap kefahaman konseptual terhadap KPS

\begin{tabular}{cccc|ccc}
\hline Demografik & & $\mathrm{N}$ & Mean Rank & $\mathrm{x}^{2}$ & $\mathrm{~d} f$ & sig. \\
\hline Pengalaman & $1-5$ tahun & 51 & 33.00 & & & \\
Mengajar Sains & $6-10$ tahun & 10 & 29.05 & 11.716 & 2 & 0.003 \\
& $11+$ tahun & 9 & 56.83 & & & \\
\hline
\end{tabular}

\section{(iii) Analisis Tahap Penguasaan terhadap KPS}

Ujian Mann-Whitney menunjukkan terdapat perbezaan yang signifikan ( $\mathrm{p}=.009<$ .05) dalam tahap penguasaan terhadap KPS bagi guru major sains dengan guru bukan major sains yang memihak kepada guru sains major yang mempunyai mean rank tahap penguasaan terhadap KPS yang lebih tinggi. Jadual 4 melaporkan hasil analisis Ujian Mann-Whitney untuk membandingkan tahap penguasaan terhadap KPS dalam kalangan guru sains SJKC berdasarkan opsyen guru. 
TAHAP KEBIASAAN, KEFAHAMAN KONSEPTUAL, PENGUASAAN DAN MINAT TERHADAP KEMAHIRAN PROSES SAINS DALAM KALANGAN GURU SAINS SJKC

Jadual 4 Perbandingan tahap penguasaan terhadap KPS berdasarkan opsyen

\begin{tabular}{|c|c|c|c|c|c|c|c|c|}
\hline Demografik & & $\mathrm{N}$ & $\begin{array}{l}\text { Mean } \\
\text { Rank }\end{array}$ & $\begin{array}{l}\text { Sum of } \\
\text { Ranks }\end{array}$ & $\mathrm{U}$ & W & $\mathrm{Z}$ & sig. \\
\hline \multirow[t]{2}{*}{ Opsyen } & Sains & 10 & 51.05 & 510.5 & \multirow{2}{*}{144.5} & \multirow{2}{*}{1974.5} & \multirow{2}{*}{-2.619} & \multirow{2}{*}{0.009} \\
\hline & Lain-lain & 60 & 32.91 & 1974.5 & & & & \\
\hline
\end{tabular}

Hasil analisis Ujian Kruskal-Wallis bagi tahap penguasaan terhadap KPS berdasarkan umur dipaparkan dalam Jadual 5. Terdapat perbezaan yang signifikan dalam tahap penguasaan KPS berdasarkan umur $(\mathrm{p}=.038<.05)$. Penganalisisan lanjutan melalui Ujian Post-Hoc mendapati guru yang berumur 36 sehingga 40 tahun mencapai mean rank yang lebih tinggi dan signifikan $(\mathrm{p}=.005<.05)$ berbanding dengan guru yang berumur 24 sehingga 30 tahun, dan juga lebih tinggi dan signifikan $(\mathrm{p}=.012<.05)$ berbanding dengan guru yang berumur 46 tahun dan ke atas.

Jadual 5 Perbandingan tahap penguasaan terhadap KPS berdasarkan umur

\begin{tabular}{ccccccc}
\hline Demografik & & $\mathrm{N}$ & Mean Rank & $\mathrm{x}^{2}$ & $\mathrm{~d} f$ & sig. \\
\hline Umur & $24-30$ tahun & 39 & 32.51 & & & \\
& $31-35$ tahun & 14 & 40.39 & & & \\
& $36-40$ tahun & 7 & 55.14 & 10.18 & 4 & 0.038 \\
& $41-45$ tahun & 2 & 26.25 & & & \\
& $46+$ tahun & 8 & 26.63 & & & \\
\hline
\end{tabular}

\section{(iv) Analisis Tahap Minat Terhadap KPS}

Ujian Kruskal-Wallis menunjukkan bahawa terdapat perbezaan yang signifikan ( $\mathrm{p}=$ $.017<.05$ ) dalam tahap minat terhadap KPS bagi guru sains berdasarkan pengalaman mengajar sains sebagaimana yang dipaparkan dalam Jadual 6. Penganalisisan lanjutan melalui Ujian Post-Hoc mendapati guru sains yang menghadiri 0 hingga 2 kali kursus sains mempunyai tahap minat yang lebih tinggi dan signifikan ( $\mathrm{p}=$ $0.027<.05$ ) berbanding dengan guru sains yang yang pernah menghadiri sebanyak 3 hingga 6 kali kursus sains, dan juga lebih tinggi dan signifikan $(p=.031<.05)$ berbanding dengan guru yang menghadiri sebanyak 7 hingga 10 kali. Dalam pada itu, guru yang telah menghadiri 11 kali dan ke atas (11+) kursus sains mempunyai tahap minat terhadap KPS yang lebih tinggi dan signifikan $(\mathrm{p}=.03<.05)$ berbanding dengan guru yang telah menghadiri kursus sebanyak 3 hingga 6 kali, dan juga lebih tinggi dan signifikan $(\mathrm{p}=.045<.05)$ berbanding dengan guru yang menghadiri 7 hingga 10 kali kursus sains. Jadual 6 di bawah menunjukkan hasil analisis yang signifikan bagi Ujian Kruskal-Wallis berdasarkan bilangan kursus sains yang pernah dihadiri oleh guru sains. 
Jadual 6 Perbandingan tahap minat terhadap KPS

\begin{tabular}{ccccccc}
\hline Demografik & & $\mathrm{N}$ & Mean Rank & $\mathrm{x}^{2}$ & $\mathrm{~d} f$ & sig. \\
\hline Bilangan & $0-2$ & 42 & 39.44 & & & \\
Kursus Sains & $3-6$ & 18 & 27.36 & & & \\
Yang Pernah & $7-10$ & 3 & 12.67 & 10.173 & 3 & 0.017 \\
Dihadiri & 7 & 42.57 & & & \\
& $11+$ & 7 & & &
\end{tabular}

\section{PERBINCANGAN DAN INTERPRETASI}

Dapatan kajian bagi tahap kebiasaan, tahap kefahaman konseptual, tahap penguasaan dan tahap minat guru sains SJKC terhadap KPS berdasarkan enam kumpulan demografik, yakni, jantina, umur, pengalaman mengajar sains, bilangan kursus yang pernah dihadiri, opsyen, dan tahap yang diajar dirumuskan dalam Jadual 7.

Jadual 7 Rumusan Dapatan Kajian

\begin{tabular}{|c|c|c|c|c|}
\hline Demografi & $\begin{array}{l}\text { Tahap } \\
\text { Kebiasaan } \\
\text { terhadap KPS }\end{array}$ & $\begin{array}{l}\text { Tahap } \\
\text { Kefahaman } \\
\text { Konseptual } \\
\text { terhadap KPS }\end{array}$ & $\begin{array}{l}\text { Tahap Penguasaan } \\
\text { terhadap KPS }\end{array}$ & $\begin{array}{l}\text { Tahap Minat } \\
\text { terhadap KPS }\end{array}$ \\
\hline Jantina & $\begin{array}{l}\text { Tidak } \\
\text { Signifikan }\end{array}$ & Tidak Signifikan & Tidak Signifikan & Tidak Signifikan \\
\hline Umur & $\begin{array}{l}\text { Tidak } \\
\text { Signifikan }\end{array}$ & Tidak Signifikan & $\begin{array}{l}(36-40)>(24-30) \\
(36-40)>(46+)\end{array}$ & Tidak Signifikan \\
\hline $\begin{array}{l}\text { Pengalaman } \\
\text { Mengajar Sains }\end{array}$ & $(11+)>(1-5)$ & $\begin{array}{l}(11+)>(1-5) \\
(11+)>(6-10)\end{array}$ & Tidak Signifikan & Tidak Signifikan \\
\hline $\begin{array}{l}\text { Bilangan } \\
\text { Kursus Yang } \\
\text { Pernah Dihadiri }\end{array}$ & $\begin{array}{l}(3-6)>(0-2) \\
(11+)>(0-2)\end{array}$ & Tidak Signifikan & Tidak Signifikan & $\begin{array}{l}(0-2)>(3-6) \\
(0-2)>(7-10) \\
(11+)>(3-6) \\
(11+)>(7-10)\end{array}$ \\
\hline Opsyen & $\begin{array}{l}\text { Tidak } \\
\text { Signifikan }\end{array}$ & Tidak Signifikan & (Sains) > (lain) & Tidak Signifikan \\
\hline $\begin{array}{l}\text { Tahap yang } \\
\text { diajar }\end{array}$ & $\begin{array}{l}\text { Tidak } \\
\text { Signifikan }\end{array}$ & Tidak Signifikan & Tidak Signifikan & Tidak Signifikan \\
\hline
\end{tabular}

Berdasarkan Jadual 7, didapati tiada perbezaan merentas keempat-empat tahap kebiasaan, tahap kefahaman konseptual, tahap penguasaan, dan tahap minat terhadap KPS berdasarkan jantina dan juga tahap kelas yang diajar.

Dari segi tahap kebiasaan terhadap KPS, guru yang mempunyai pengalaman mengajar 11 tahun dan ke atas mencapai lebih tinggi secara statistik berbanding dengan guru yang berpengalaman mengajar sains selama 1 hingga 5 tahun. Juga, guru sains yang menghadiri 3 hingga 6 kursus, dan juga yang pernah menghadiri 
TAHAP KEBIASAAN, KEFAHAMAN KONSEPTUAL, PENGUASAAN DAN MINAT TERHADAP KEMAHIRAN PROSES SAINS DALAM KALANGAN GURU SAINS SJKC

11 kursus dan ke atas mencapai lebih tinggi secara statistik berbanding dengan guru sains yang menghadiri 0 hingga 2 tahun.

Dari segi tahap kefahaman konseptual terhadap KPS, guru sains yang berpengalaman mengajar 11 tahun dan ke atas mencapai lebih tinggi secara statistik berbanding dengan guru sains yang berpengalaman mengajar 1 hingga 5 tahun, dan juga berbanding dengan guru sains yang mengajar 6 hingga 10 tahun.

Dari segi penguasaan terhadap KPS, guru sains yang berumur antara 36 hingga 40 tahun mencapai suatu tahap yang lebih tinggi secara statitik berbanding dengan guru sains yang berumur 24 hingga 30 tahun, dan juga 46 tahun dan ke atas. Tambahan pula, guru beropsyen sains mencapai tahap penguasaan terhadap KPS yang lebih tinggi secara statistik berbanding dengan guru yang bukan beropsyen sains.

Dari segi tahap minat terhadap sains, guru yang telah menghadiri sebanyak 0 hingga 2 kursus mencapai suatu tahap yang lebih tinggi secara statistik berbanding dengan guru yang telah menghadiri 3 hingga 6 kursus, dan juga 7 hingga 10 kursus. Guru yang telah menghadiri 11 kursus dan ke atas mencapai suatu tahap minat terhadap KPS yang lebih tinggi secara statistik berbanding dengan guru yang menghadiri 3 hingga 6 kurus, dan juga 7 hingga 10 kursus.

Tahap kebiasaan terhadap KPS yang lebih tinggi dalam kalangan guru yang berpengalaman mengajar sains 11 tahun dan ke atas berbanding dengan guru yang berpengalaman mengajar sains 1 hingga 5 tahun adalah dijangkakan memandangkan guru sains-guru sains yang berpengalaman mengajar sains 1 hingga 5 tahun yang lumrahnya dikenali sebagai guru novis (Caspersen \& Raaen, 2014) baharu sahaja membiasakan diri terhadap KPS. Sebaliknya, guru yang mengajar sains selama 11 tahun dan ke atas yang dikenali sebagai guru pakar telahpun berjinak sehingga sangat biasa terhadap KPS.

Selain itu, dapatan kajian juga menunjukkan bilangan kursus sains yang pernah dihadiri juga mempengaruhi tahap kebiasaan guru sains terhadap KPS. Tahap kebiasaan terhadap KPS bagi guru sains yang tidak pernah atau hanya pernah menghadiri kursus sebanyak satu atau dua kali adalah berbeza dengan guru yang menghadiri kursus sains sebanyak 3 sehingga 6 kali dan guru yang menghadiri kursus sains melebihi 10 kali. Guru sains yang kerap menghadiri kursus sains lumrahnya adalah biasa terhadap KPS berbanding dengan guru yang jarang menghadiri kursus kerana kursus adalah jambatan yang terbaik untuk menerapkan KPS dalam kalangan guru (Miles, 2010).

Kajian ini mendapati terdapat perbezaan yang signifikan dalam guru sains SJKC yang berbeza pengalaman mengajar sains mereka. Tahap kefahaman konseptual bagi guru yang baharu mengajar sains 1 hingga 5 tahun adalah berbeza dengan guru yang berpengalaman mengajar selama 11 tahun dan ke atas dan guru yang mengajar selama 6 hingga 10 tahun juga berbeza tahap kefahaman konseptual mereka dengan guru yang mengajar 11 tahun dan ke atas. Ini jelas menunjukkan pengalaman mengajar seseorang guru sains mempengaruhi tahap kefahaman konseptualnya terhadap KPS dan guru yang tinggi kefahaman konseptual dalam KPS adalah guru yang berpengalaman (Miles, 2010). 
Kajian juga mendapati tahap penguasaan terhadap KPS oleh guru beropsyen sains adalah lebih baik berbanding dengan guru yang bukan beropsyen sains. Hal ini berlaku mungkin kerana guru yang beropsyen sains sememangnya pernah diberikan pendedahan kepada KPS semasa mereka mengikuti kursus ijazah sarjana muda pendidikan mahupun diploma pendidikan lepasan ijazah di instituti pendidikan tinggi khasnya dalam komponen pendidikan ikhtisas yang diambil, manakala guru bukan beropsyen sains yang tidak didedahkan kepada KPS mempunyai tahap penguasaan terhadap KPS yang lebih rendah.

Dalam pada itu, guru sains yang berumur 36 sehingga 40 tahun adalah golongan guru sains yang tahap penguasaan KPS mereka adalah pada tahap yang paling tinggi. Sebagai pengimbauan, Penilaian Kerja Amali (PEKA) mula dilaksanakan pada tahun 2008. Lantaran itu, sebelum pelaksanaan PEKA, guruguru sains pernah dipanggil untuk menghadiri kursus mengenai pelaksanaan PEKA sebagai orientasi atau persediaan untuk menghadapi pelaksanaan PEKA.

Dapatan kajian menunjukkan bilangan kursus sains yang pernah dihadiri oleh guru sains SJKC mempengaruhi tahap minat mereka untuk belajar KPS dengan lebih lanjut. Analisis kajian mendapati guru sains yang tidak pernah atau pernah menghadiri satu atau dua kali kursus sains serta guru yang telah menghadiri melebihi 10 kali kursus sains adalah lebih berminat untuk mempelajari KPS dengan lebih lanjut. Memandangkan bahawa kebanyakan guru yang jarang menghadiri kursus sains adalah guru novis, maka mereka berkeinginan untuk mengetahui yang seterusnya dijelmakan dalam tahap minat yang lebih tinggi terhadap KPS. Tambahan pula, guru yang telah banyak kali menghadiri kursus sains masih berminat untuk mempelajari KPS dengan lanjut berbanding dengan guru yang lain merupakan suatu fenomena positif yang sejajar dengan pembelajaran sepanjang hayat (lifelong learning) (Demirel, 2009).

Sebagai penutup, perlu ditegaskan bahawa seorang guru sains haruslah menguasai KPS terlebih dahulu sebelum beliau boleh mengajar KPS kepada anak muridnya (Radford, 1992). Selain itu, menurut Azraai, Fazilah dan Othman (2016), penggunaan KPS dalam penyelesaian masalah juga memberi peluang kepada murid untuk meneroka masalah dalam kehidupan seharian mereka. Lantaran itu, pengenalpastian tahap kebiasaan, tahap kefahaman konseptual, tahap penguasaan dan tahap minat terhadap KPS oleh guru sains haruslah sentiasa diutamakan dan dipantau oleh guru sains secara kendiri, ketua panitia sains, ataupun pihak Jemaah Nazir dan Jaminan Kualiti (JNJK).

\section{RUJUKAN}

Abu Hassan Kassim. (2007). Pendidikan Amali Sains: Kemahiran Saintifik. Skudai: Penerbit UTM

Ary, D., Jacobs, L.C., Razavieh, A., \& Sorenson, C. (2006). Introduction to Research in Education ( $7^{\text {th }}$. ed.). Belmont, CA: Wadsworth. 
TAHAP KEBIASAAN, KEFAHAMAN KONSEPTUAL, PENGUASAAN DAN MINAT TERHADAP KEMAHIRAN PROSES SAINS DALAM KALANGAN GURU SAINS SJKC

Abungu, H.E., Okere, M.I.O., \& Wachanga, S.W. (2014). The Effect of Science Process Skills Teaching Approach on Secondary School Students' Achievement in Chemistry in Nyando District, Kenya. Journal of Educational and Social Research, 4(6), 359-372.

Aziz Nordin \& Lin, H. L. (2011). Hubungan Sikap Terhadap Mata Pelajaran Sains Dengan Penguasaan Konsep Asas Sains Pelajar Tingkatan Dua. Journal of Science \& Mathematics Educational, 2, 89-101.

Azraai Othman, Fazilah Razali \& Othman Talib (2016). Aplikasi kemahiran proses sains dalam Pembelajaran Berasaskan Masalah untuk mata pelajaran Biologi. Jurnal Kurikulum dan Pengajaran Asia Pasifik, 4(3), 38-46.

Bahagian Pembangunan Kurikulum. (2013). Pendekatan inkuiri melalui penguasaan kemahiran proses sains. Putrajaya: Kementerian Pendidikan Malaysia.

Berg, E. (2008). Improving teaching in the laboratory: Old problems, new perspectives. Kertas Kerja Seminar Pembelajaran dan Pengajaran Sains, Universiti Kebangsaan Malaysia, 17-19 Februari.

Burns, J.C., Okey, J.R., \& Wise, K.C. (1985). Development of an integrated process skill test: TIPS II. Journal of Research in Science Teaching, 22(2), 169-177.

Caspersen, J., \& Raaen, F. D. (2014) Novice teachers and how they cope. Teachers and Teaching, 20(2), 189-211.

Chin, H. W. (2012). Kajian tentang teknik-teknik untuk meningkatkan minat dan sikap murid-murid terhadap mata pelajaran sains di Sekolah Rendah Jenis Kebangsaan Cina Pei Yuan Kampar. Retrieved 8 June, 2017 from https://www.academia.edu/6911883/KAJIAN TENTANG TEKNIK- TEKNIK_UNTUK_MENINGKATKAN_MINAT_DAN SIKAP_MURID- MURID TERHADAP_MATA_PELAJARAN SAINS DI SEKOLAH RENDAH JENIS KEBANGSAAN CINA PEI YUAN KAMPAR

Demirel, M. (2009). Lifelong learning and schools in the twenty-first century. Procedia Social and Behavioral Sciences, 1, 1709-1716.

Hariah, B. M., \& Chin, C. K. (2012). Tinjauan Tahap Pencapaian dan Pelaksanaan Kemahiran Proses Sains dalam kalangan Guru Pelatih PISMP. Retrieved 8 Jun, 2017 from https://www.academia.edu/4044925/Tinjauan Tahap Pencapaian and Pelaksanaan_Kemahiran_Proses_Sains_Dalam_Kalangan_Guru_Pelatih PISMP

Kementerian Pendidikan Malaysia. (2012). Pelan Pembangunan Pendidikan Malaysia 2013-2025. Putrajaya: Kementerian Pendidikan Malaysia.

Miles, E. (2010). In-service elementary teachers' familiarity, interest, conceptual knowledge and performance on science process skills (master's thesis). Southern Illinois University Carbondale, Carbondale, Illinois, USA.

Mohd Azri \& Siti Shahida (2016). Tahap penguasaan kemahiran proses sains bersepadu dan kemahiran abad ke-21 dalam kalangan pelajar biologi. Masters thesis, Universiti Pendidikan Sultan Idris. 
Ong, E.T., \& Johairi, A. R. (2011). Tahap Penguasaan Kemahiran Proses Sains Bersepadu (KPSB) dalam Kalangan Pelajar Tingkatan 2 di Daerah Temerloh. Jurnal Pengajian Pendidikan, 1, 1- 20.

Ong, E.T., \& Ruthven, K. (2005). Acquisition of science process skills amongst Form 3 students in Malaysian smart and mainstream schools. Journal of Science and Mathematics Education in Southeast Asia, 28(1), 103-124.

Organisation for Economic Cooperation and Development (OECD). (2017). PISA 2015: Technical Report. Paris: OECD Publishing.

Padilla, M., Cronin, L., \& Twiest, M. (1985). The development and validation of the test of basic process skills. Paper presented at the annual meeting of the National Association for Research in Science Teaching, French Lick, IN. Retrieved from ERIC Database (ED256628).

Radford, D.L., DeTure, L.R., \& Doran, R.L. (1992). A preliminary assessment of science process skills, achievement of pre-service elementary teachers. A paper presented at the annual meeting of the National Association for Research in Science Teaching, Boston, MA.

Shahrir, A.D., \& Suziela, M.T. (2011). "Backyard Science": Mengembangkan potensi pengetahuan sedia ada kanak-kanak dalam pembinaan konsep saintifik. Seminar Prosiding IPG Kampus Gaya, Sabah.

Stufflebeam, D.L. (1971). Education evaluation and decision making. Itasca, Illinois: F.E. Peacock Publisher, Inc.

Tan, M.T., \& Chin, T. P. (2001). Satu tinjauan awal konsepsi kemahiran proses sains di kalangan guru sains PKPG 14 minggu di Maktab Perguruan Batu Lintang. Unpublished journal, Maktab Perguruan Batu Lintang, Batu Lintang, Sarawak.

US Department of Education. (2005). National Assessment of Educational Progress (NAEP) Science Assessment. Institute of Education Sciences National Center for Education Statistics. Retrieved from http://nces.ed.gov/nationsreportcard/ itmrlsx/search.aspx

Wun, T.Y., \& Sunita, T. (2015). Tahap pencapaian kemahiran proses sains bersepadu dalam mata pelajaran sains dalam kalangan pelajar tingkatan lima. Journal of Science and Mathematics Letters, 3(1), 7-14.

Worthen, R., \& Sanders, R. (1998). Educational evaluation: Alternative approaches and practical guidelines. New York: Longman. 